\title{
舌根部より発生した悪性筋上皮腫例
}

\author{
奥山 晃子 1 - 渡辺 雄介 ${ }^{2)} \cdot$ 瀬尾 律 ${ }^{3)}$ \\ 仙波 治 ${ }^{2)}$ ・ 山崎 大 $^{4)}$ - 小林 晏4)
}

\section{Malignant Myoepithelioma of the Root of the Tongue}

\author{
Akiko Okuyama \\ (Sumitomo Hospital) \\ Yusuke Watanabe, Osamu Semba, Masaru Yamazaki and Yasushi Kobayashi \\ (Osaka Koseinenkin Hospital) \\ Ritsu Seo \\ (Ikeda Municipal Hospital)
}

\begin{abstract}
A case of malignant myoepithelioma originating from the root of the tongue of a 12-year-old female is described. No symptoms except the presence of a neck mass on the left-hand side of the body were recognized. A CT scan and MRI revealed a tumor shadow localized to the root of the tongue and a solitary left cervical lymph node swelling. Biopsy specimens obtained from the left cervical lymph node were studied by light microscopy with hematoxylin and eosin staining and with immunohistochemical staining. The tumor, predominantly composed of highly anaplastic small round cells, showed positive staining with antibodies to S- 100 protein, cytokeratin, vimentin and $\alpha$-smooth muscle actin, on the basis of which we diagnosed malignant myoepithelioma. We performed total extirpation of the tumor, reconstruction of the tongue defect using free radial forearm flap, and left radical neck dissection. The tumor at the root of the tongue showed a histological picture which was the same as that of the cervical lymph node specimens. This tumor was determined to have originated from the minor salivary gland of the root of the tongue. Postoperatively, the tongue and left upper neck were irradiated $(50 \mathrm{Gr}$ ). Recurrence of the tumor was observed, however, two months after surgery, in the muscular tunics of the tongue. Total extirpation of the tumor was subsequently performed, after which the clinical course has been uneventful.
\end{abstract}

Key words : malignant myoepithelioma, tongue, immunohistochemical study

\section{はじめに}

筋上皮腫は，腺組織の腺房や導管の周囲に配列する筋 上皮細胞由来の腫瘍と考兄られており, 主な発生部位は 唾液腺である1)。しかし，唾液腺腫瘍全体の中での割合 は $1 \%$ 以下と報告されて括り2), 悪性例の報告は極めて 少ない，今回舌根部の小唾液腺より発生したと考兄られ
た悪性筋上皮腫の症例を経験したので報告する．

$$
\text { 症例 }
$$

患者: 12歳, 女児.

主訴: 左頸部腫瘤.

現病歴: 平成 7 年 9 月末, 偶然母親によって左頸部腫
1) 住友病院耳鼻咽喉科

3）市立池田病院耳鼻咽喉科
2）大阪厚生年金病院耳鼻咽喉科

4）大阪厚生年金病院臨床病理検査科 
瘤を発見され，徐々に増大するため 10 月 30 日に当科を受 診した。

初診時所見：舌根部に弾性硬, 辺縁不明瞭な腫瘤と左 頸部に $60 \times 40 \mathrm{~mm}$ の転移と思われる腫瘤を認めた(図 1)。な抏，顔面神経麻疩および舌下神経麻痺は認めな かった。

既往歷 : 特記すべきことなし。

家族歴：特記すべきことなし。

画像診断：CTにて左舌根部から口腔内左側壁にかけ て不均一飞造影される腫瘤陰影と左頸部に約 $4 \mathrm{~cm}$ 大の リンパ節腫脤像を認めた。

MRI 水平断では, T1 強調像で筋肉と等信号を示し, ガドリニウムにより不均一に増強され，T2 強調像で高 信号を示す腫瘤陰影を認めた。腫瘤は舌根部左側から正 中を越光右側まで広がっていた(図 2).

胸部 X線検查，全身ガリウムシンチ，腹部エューでは 遠隔転移の所見は認められなかった。

病理組織学的所見：初診時舌根部より行った生検では， 扁平上皮の過形成のみを認めた．舌根部腫瘍上りの左頸 部転移が疑われたこと沶よび十分量の生検組織が得られ ることを考克，外切開による左頸部リンパ節の生検を行

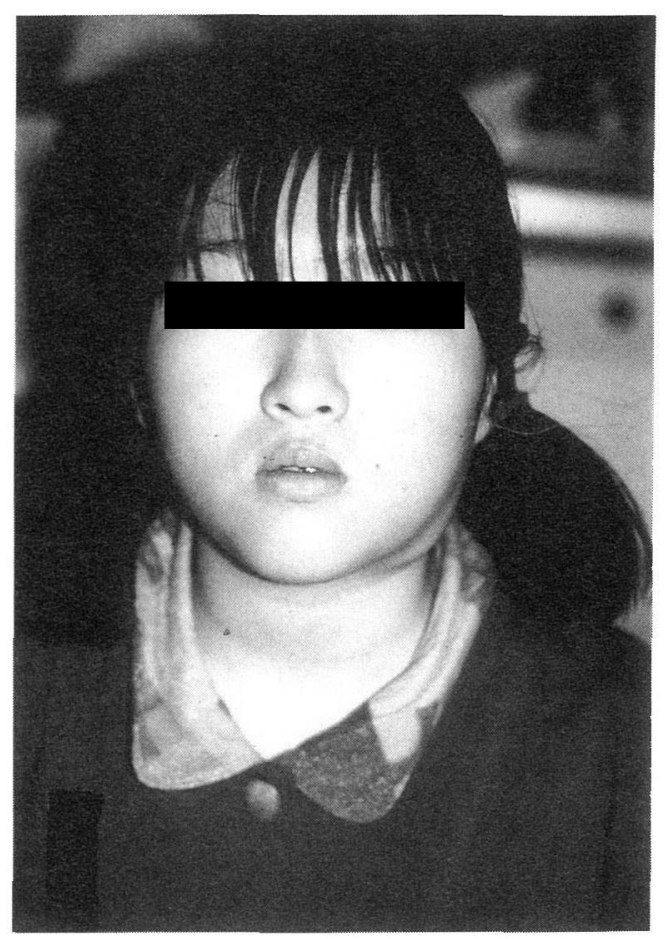

図 1 入院時左側頸部腫瘤

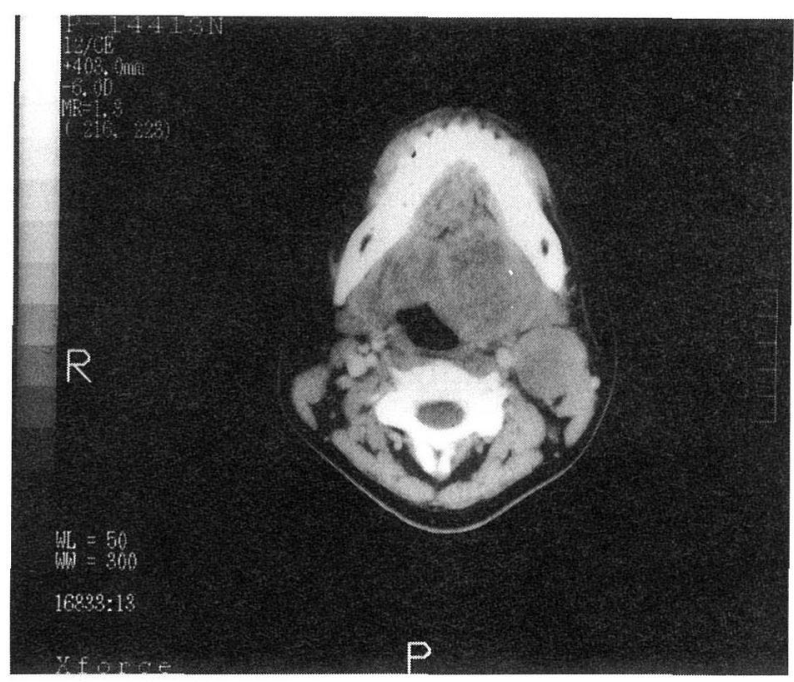

a

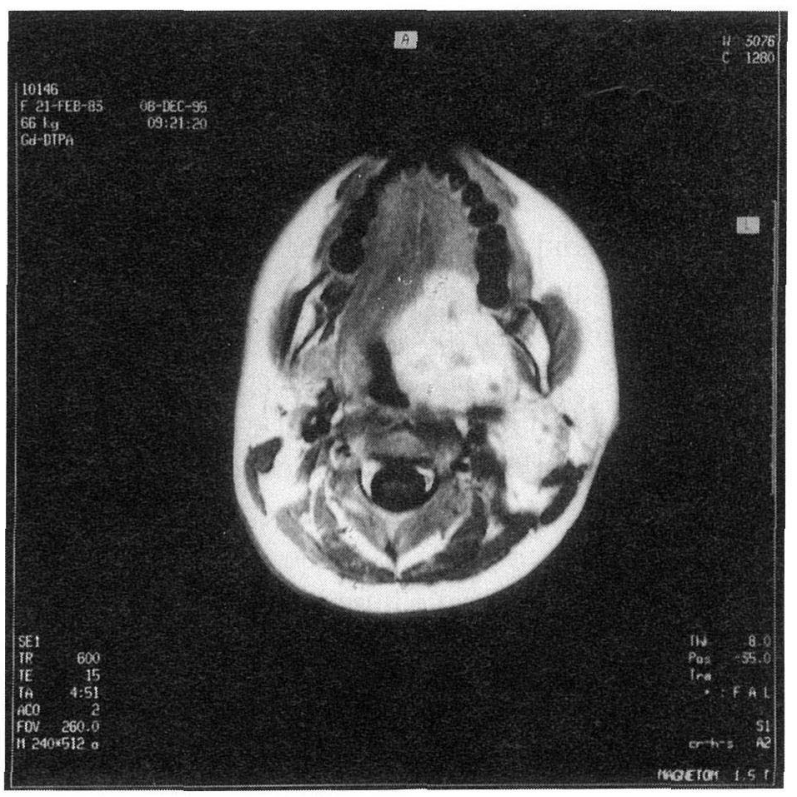

b

図 2 入院時 $\mathrm{CT}$ 抢上び MRI

a : 造影 CT

舌根部特上び左頸部に腫瘍陰影を認める。

$\mathrm{b}: \mathrm{MRI}$ 水平断 ( $\mathrm{T} 1$ 強調, $\mathrm{Gd}$ 造影像)

舌根部左側から右側飞広がり, 内部に不均一な低信 号領域を伴う腫瘍陰影を認める。

った。

HE 染色では比較的小型で類円形の腫瘍細胞が充実性 飞增殖する像を呈していた。また，核分裂像扒よび無数 の血管侵襲像と，一部に被膜外人の浸潤性増殖像を認め 
た.

免疫組織化学染色では腫瘍細胞は S-100 蛋白, cytokeratin, vimentin, $\alpha$-smooth muscle actin が陽性で, GFAP (glial fibrillary acidic protein), desmin, myosin

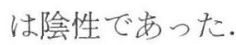

電顕では，ミトコンドリア，粗面小胞体などの細胞小 器官がわずかに認められ, 細胞質内に microfilament が 散在していた(図3).

以上の所見より, 舌根部の小睡液腺から発生した悪性 筋上皮腫と考兄られた。

臨床経過: 平成 7 年12月18日, 全身麻酔下漳腫瘍摘出 術を行った。まず左根本的頸部郭清術を行い, その後舌 根部の腫瘍を剥離し，下靧骨下に引き出し摘出した。腫 瘍と周囲組織との剥離は比較的容易であった。腫瘍切除 後に舌根部に生じた粘膜欠損部は右遊離前腕皮弁 $(4 \times 4$ $\mathrm{cm}$ 劣用いて再建した。

舌根部よりの摘出標本に执いても頸部腫瘍之同様の組 織像を示与腫瘍細胞が認吼た(図 4). また免疫組織 化学的検索にても同様の結果が得られた(図 5 ).

以上より, 舌根部の小唾液腺から発生した悪性筋上皮 腫と確診した。

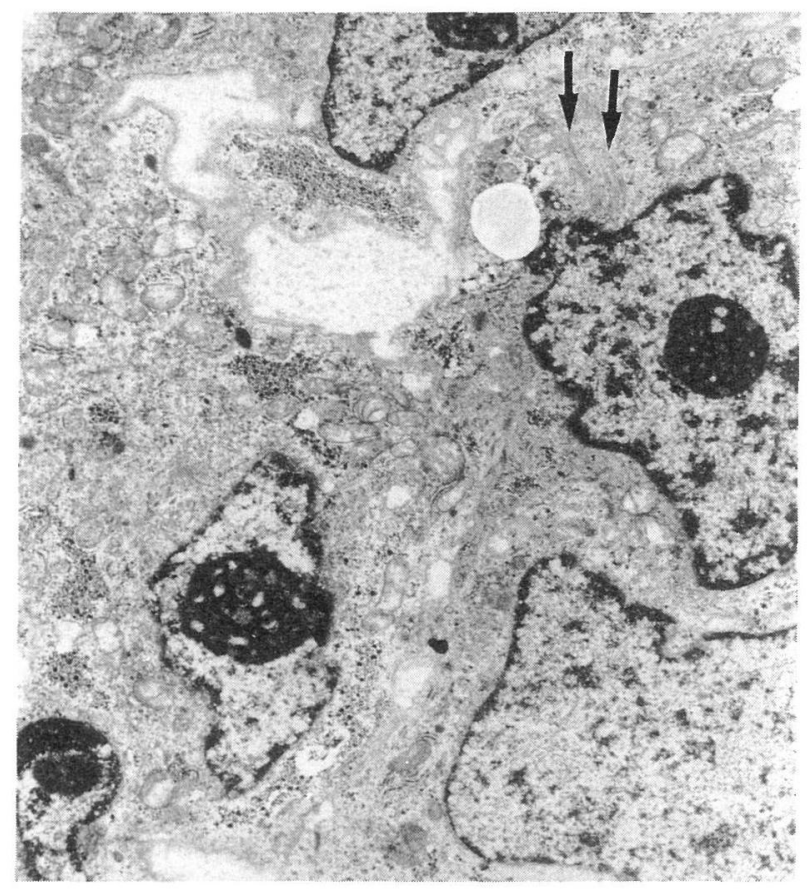

図 3 電䫒像 $(\times 4000)$

細胞質内に microfilament 莸認める。

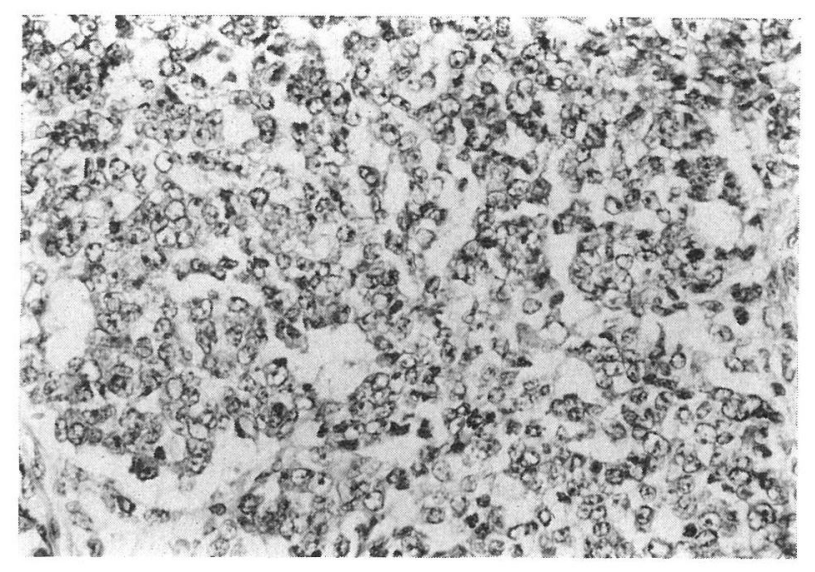

図 4 病理組織像 (舌根部腫瘍, HE 染色) $(\times 100)$ 類円形腫瘍細胞の充害性増殖を示寸。

術後 3 週後より，再発防止効果を期待し，舌执よび左

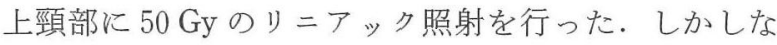
がら照射終了 2 週後には, 舌筋層内に弾性硬の腫瘤を触 れ，針生検を行ったところ，前回と同様の腫瘍細胞が認 められた． MRI， T2 強調画像にても舌左縁から前方に かけて高信号領域が認められた(図6).

平成 8 年 3 月 11 日, 再び全身麻酔下に腫瘍摘出術を行 った． 口腔より腫瘍にアプローチした後, 顎下部に切開 を入れ，腫瘍を約 $10 \mathrm{~mm}$ の安全域を付计て摘出した。

術後経過良好にて，4月 9 日退院となり，現在外来に て経過観察中である。

\section{考察}

筋上皮細胞は, 唾液腺, 涙腺, 汗腺, 乳腺などに存在 し, それらの腺組織の腺房や導管の介在部の上皮細胞を 取り因むような形で配列して和り，その收縮が分泌物の 放出を促進すると考光られている ${ }^{3)}$ 。 また平滑筋細胞と 類似の機能を持ちながら，上皮性の発生由来をもつ特異 な性格の細胞である4).

筋上皮腫の名称は，1943年に Sheldon ${ }^{5}$ が54例の耳下 腺混合腫瘍を組織学的に検討乙, 腫瘍細胞のほとんどが 筋上皮細胞で構成されている 3 例を筋上皮腫としたこと 飞始まる。矢の発生頻度は, 全哽液腺腫瘍の $1 \%$ 以下之 報告されている2)、特に悪性例の報告は極めて少なく, 頭頸部領域に括计る悪性筋上皮腫の報告は, 我々が検索 乙得た範囲では自験例を含め12例であった(表 1 ) 6) 16). 性別では男性 4 例, 女性 8 例で，65歳以上の高齢者が 


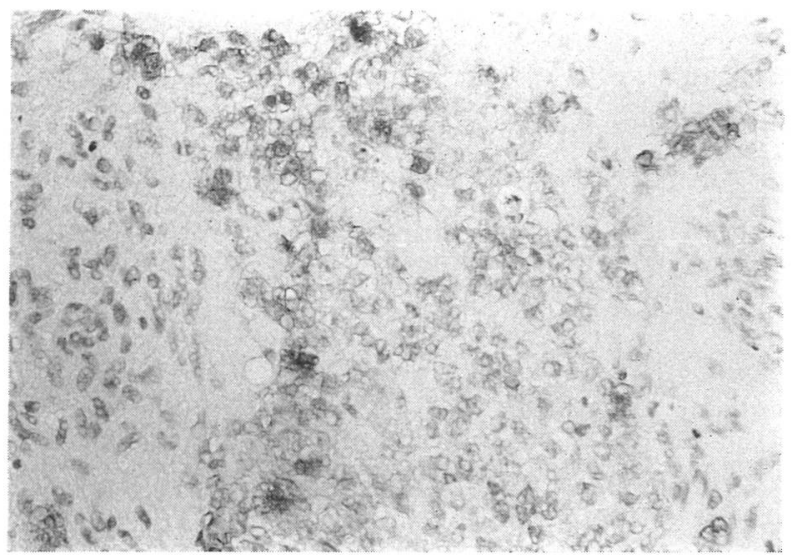

a

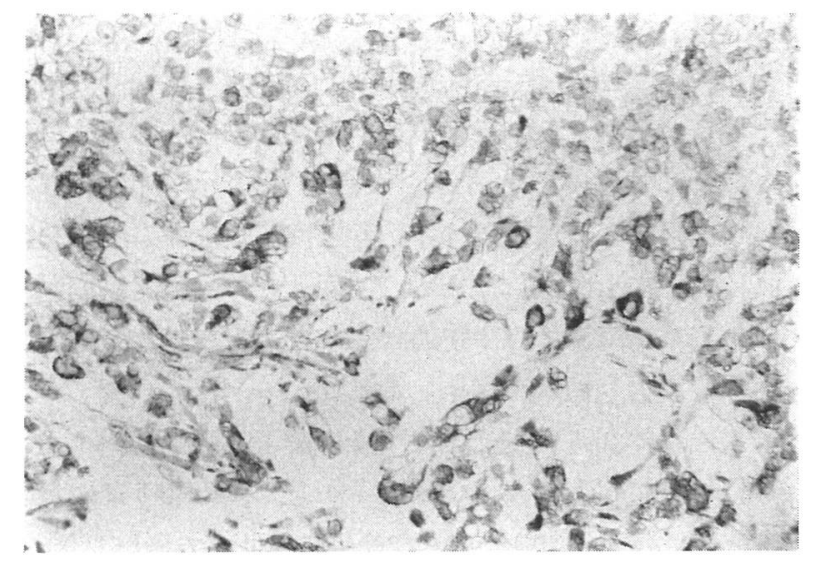

c

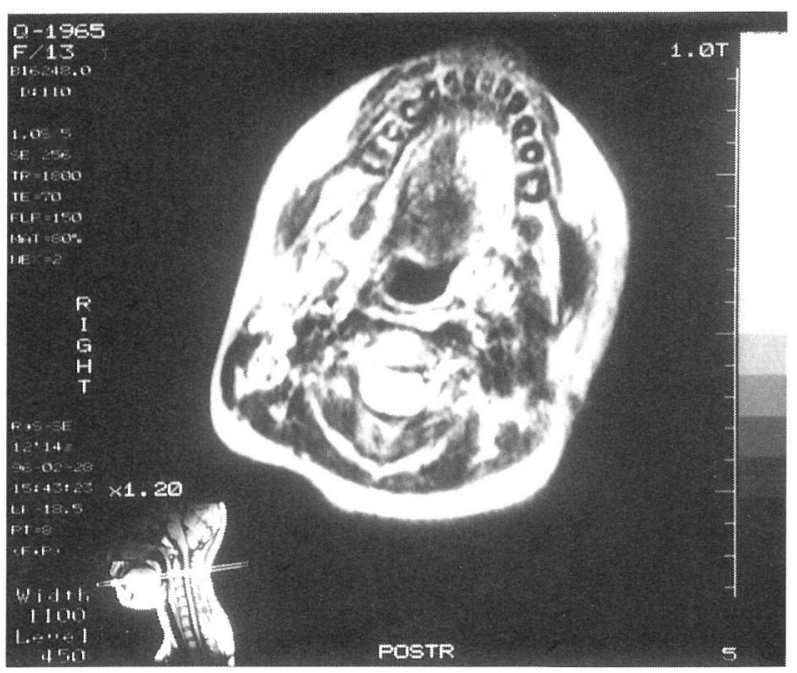

図 6 再発時 MRI 水平断 (T2 強調画像) 舌左縁に高信号領域を認める。

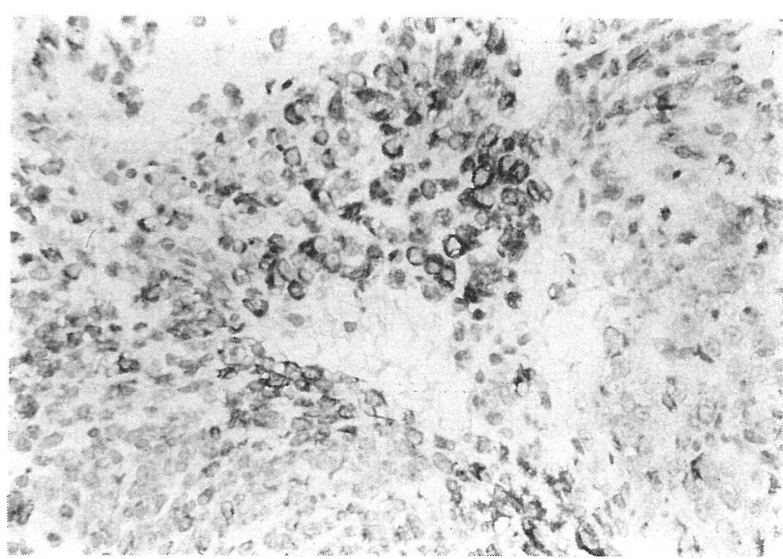

b

図 5 免疫染色像(舌根部腫瘍)

S-100蛋白, cytokeratin, vimentin に陽性を示した。

a : S-100 蛋白 $(\times 200)$

b : cytokeratin $(\times 200)$

c : vimentin $(\times 200)$

9 例と多数を占めていた。発生部位は，耳下腺が 6 例， 口蓋が 2 例, 歯肉部, 鼻腔, 喉頭が各 1 例であり, 舌に 発生したものは本例のみであった.

筋上皮腫は組織学的に, 紡錘型細胞の増殖を主体とす る spindle cell type, 形質細胞類似の細胞の増殖を主体 とする plasmacytoid cell type 执よび両者の混合よりな る mixed typeの3 型に大別されるが2), 午の他に, clear cell を主体とする症例17) や，類门形・多角形腫瘍 細胞の充実性増殖を示す症例7)15) が報告されている．本 症例では類円形腫瘍細胞の充実性増殖を認め, 後者に相 当するものと思われた。

近年, 免疫組織学的研究により, 腫瘍細胞の由来につ いての解明が進えで和り, 筋上皮細胞执よび笳上皮腫に ついても種々の検討が行われている。筋上皮細胞は機能 的には平滑笳細胞に類似しているが，上皮細胞のマー カーである cytokeratin ${ }^{18)}$ が陽性で, 間葉系細胞のマー 
表 1 頭頸部領域における悪性筋上皮腫報告例

\begin{tabular}{|c|c|c|c|c|c|c|c|}
\hline & 報 告 者 & 報告年 & 部 位 & 年齢 & 性 & 治 & 経 \\
\hline 1 & Stromeyer $5^{6)}$ & 1975 & 歯肉部 & 14 & 男 & 放射線, 手術 & 15力月非担癌生存 \\
\hline 2 & Crissman $5^{7)}$ & 1977 & 左耳下腺 & 81 & 男 & 放射線 & 6 週後右鼠径部に転移 \\
\hline 3 & Dardick $^{8)}$ & 1985 & 右耳下腺 & 86 & 女 & 手術 & 3 年非担癌生存 \\
\hline 4 & 甲田 $5^{9)}$ & 1986 & 右耳下腺 & 66 & 女 & 手術, 放射線 & 4 年後局所再発, 肺転移 \\
\hline 5 & Singh $5^{10)}$ & 1988 & 耳下腺 & 66 & 女 & 施行せず & 初診 2 週後に肺炎で死亡 \\
\hline 6 & Palma $5^{11)}$ & 1991 & 耳下腺 & 39 & 女 & 手術 & 不明 \\
\hline 7 & Ibrahim $5^{12)}$ & 1991 & 喉頭 & 71 & 男 & 放射線, 化学療法 & 肺転移, 3 力月後死亡 \\
\hline 8 & Takeda $5^{13)}$ & 1992 & 硬口蓋 & 73 & 男 & 放射線, 手術 & 12 力月非担癌生存 \\
\hline 9 & 木村 $5^{14)}$ & 1994 & 右耳下腺 & 81 & 女 & 手術 & 3 年非担癌生存 \\
\hline 10 & 新宅ら ${ }^{15)}$ & 1994 & 軟口蓋 & 68 & 女 & 化学療法, 手術 & 頭蓋内浸潤, 5 力月後死亡 \\
\hline 11 & 宇野ら ${ }^{16)}$ & 1994 & 鼻腔 & 66 & 女 & 手術, 放射線 & 11力月非担癌生存 \\
\hline 12 & 自験例 & 1996 & 舌根部 & 12 & 女 & 手術, 放射線 & 生存治療中 \\
\hline
\end{tabular}

カーである vimentin および筋由来の中間径細胞骨格線 維である desmin が陰性であることから上皮性の由来で あるとされている19)。一方，筋上皮腫では多くの症例で， cytokeratin 以外飞 vimentin, S-100 蛋白が陽性を示すと 報告されて括り，本症例でも同様の所見が得られた。

S-100 蛋白は神経組織などに存在するカルシウム結合 蛋白で, 唾液腺では筋上皮細胞のマーカーとして利用さ れてきた20). しかし最近では, 正常筋上皮細胞では必ず しも陽性を示さず, 腫瘍性筋上皮細胞に強陽性反応を示 すことが多いと報告されている21)。また，S-100 蛋白は， 神経組織以外に軟骨や筋肉など間葉系細胞で陽性を示す ことが知られて扣り，筋上皮への分化よりもむしろ間葉 系化生を示すマーカーであるとも考兄られている22).

$\alpha$-smooth muscle actin, myosin は筋肉系細胞の細胞 骨格線維, GFAP は神経膠細胞由来の中間径線維であ るが，これらに対する染色性は症例によって様々である.

腫瘍性筋上皮細胞が，正常筋上皮細胞とは異なる多様 な染色性を示すことについて，二階ら22)は，腫瘍性筋 上皮細胞が，正常筋上皮細胞のすべての性格を兼ね備兄 るとは限らず, 異常な細胞分化や化生によって修飾され て扣り，正常唾夜腺では認められない形質発現を伴うよ らになるためであると述べている.多様に分化，修飾さ れた腫瘍性筋上皮細胞に执いて単独で指標となるるのは なく, 腫瘍の由来が筇上皮細胞であるかどうかに関して は, 通常いくつかのマーカーを組み合わせて判定が行わ
れている.

治療法については, 放射線療法にて腫瘍の縮小が認め られたといら報告もあるが7，大部分の報告では手術療 法のみが有効であったとされている．化学療法について も，奏効例の報告はなく，他の腺系癌と同様に放射線療 法や化学療法の効果は少ないと予想される.

本症例では, 初診時頸部リンパ節転移を認め, また組 織学的にも悪性度は高いと考兄られた．放射線療法の効 果の有無は明確にはされていないため, 付加的効果を期 待して術後放射線照射を行ったが，早期に照射野内に局 所再発を来たした。そのため再度腫瘍摘出術を行わざる を得なかった. 今回の症例からも，悪性筋上皮腫に対し て放射線療法の効果は殆ど期待できず, 根治治療として は，十分な安全域を取った手術を行らことが重要である と考えられた。

これまでの報告によれば，平均18力月の観察期間で， 原病死が 3 例, リン八゚節転移が 2 例, 肺転移, 肝転移が それぞれ 1 例となって括り，予後は必ずしも良好とは言 えない，本症例も，引き続き厳重な経過観察が必要であ ると思われる。

$$
\text { まとめ }
$$

（1）舌根部に発生した悪性筋上皮腫の1例について, 若干の文献的考察を加え報告した.

（2）腫瘍摘出術および頸部郭清術を施行後，放射線照 
射を行ったが，局所再発を来たした．再度腫瘍摘出術を 行った後, 経過観察中である. 悪性筋上皮腫の治療とし て，放射線療法の有効性は低く，手術による十分な安全 域を取った腫瘍摘出の重要性を示す症例と思われた.

本論文の要旨は第256回日本耳鼻咽喉科学会大阪地方連合会 (平成 8 年 3 月 9 日, 大阪市) に扮いて口演した.

\section{参考文献}

1) 長尾孝一：唾夜腺腫瘍の分類ならびにまれな腫瘍の解説. 病理之臨床 $7: 560 \sim 573,1989$.

2 ) Sciubba JJ and Brannon RB : Myoepithelioma of salivary glands ; report of 23 cases. Cancer $49: 562 \sim 572,1982$.

3 ) 藤田尚男, 藤田恒夫 : 標準組織学各論第 2 版. 103頁, 医 学書院, 東京, 1984.

4 ）藤田尚男, 藤田佰夫 : 標準組織学総論第 3 版. 111頁, 医 学書院, 東京, 1988.

5 ) Sheldon WH : So-called mixed tumors of the salivary glands. Arch Pathol 35 : 1 20, 1943.

6 ) Stromeyer FW, Haggitt RC, Nelson JF, et al : Myoepithelioma of minor salivary gland origin. Arch Pathol 99 : 242 245, 1975.

7) Crissman JD, Wirman JA and Harris A: Malignant myoepithelioma of the parotid gland. Cancer $40: 3042 \sim$ 3049, 1977.

8 ) Dardick I : Malignant myoepithelioma of parotid salivary gland. Ultrastruct Pathol $9: 163 \sim 168,1985$.

9 ）甲田賢治, 小川 博, 喜納 勇: 耳下腺悪性筋上皮腫の 1 症例. 病院病理 $4: 78,1986$.

10) Singh R and Cawson RA : Malignant myoepithelial carcinoma (myoepithelioma) arising in a pleomorphic adenoma of the parotid gland. Oral Surg $66: 65 \sim 70,1988$.

11) Palma SD, Pilotti $S$ and Rilke F : Malignant myoepithelioma of the parotid gland arising in a pleomorphic adenoma. Histopathology $19: 273 \sim 275,1991$.
12) Ibrahim R, Bird DJ and Sieler MW : Malignant myoepithelioma of the larynx with massive metastatic spread to the liver; an ultrastructural and immunocytochemical study. Ultrastruct Pathol $15: 69 \sim 76,1991$.

13) Takeda $Y:$ Malignant myoepithelioma of minor salivary gland origin. Acta Pathol Jpn 42 : 518 522, 1992.

14）木村 中, 吉田哲憲, 千葉 理, 他 : 耳下腺に発生した巨 大な悪性筋上皮腫の一例. 日形会誌 $14: 305 \sim 311,1994$.

15）新宅雅幸, 箕山 学: 小喠液腺悪性筋上皮腫の一例. 癌の 臨床 $40: 983 \sim 987,1994$.

16）宇野芳史, 前田 学, 斉藤龍介, 他 : 鼻腔に生じた悪性筋 上皮腫例. 耳鼻臨床 $87: 351 \sim 355,1994$.

17) Batsakis JG, Kraemer B and Sciubba JJ : The pathology of head and neck tumors ; the myoepithelial cell and its participation in salivaly gland neoplasia, part 17 . Head Neck Surg $5: 222 \sim 233,1983$.

18）向井万起男, 鳥潟親雄 : 細胞骨格 (cytoskeleton) の免疫組 織化学. 病理と臨床 6 臨時増刊号 : 161 168, 1988.

19）森永正二郎：唾液腺の解剖と腫瘍の組織発生. 病理と臨床 $7: 545 \sim 559,1989$.

20) Nakazato $Y$, Ishida $Y$, Takahashi $K$, et al : Immunohistochemical distribution of S-100 protein and glial fibrillary acidic protein in normal and neoplastic salivary glands. Virchows Arch A Pathol Anant Histopathol 405 : 299 310, 1985.

21）立本行宏, 能佐俊介, 岩井克正, 他: Carcinoma in pleomorphic adenoma 一腫瘍マーカーに関する免疫組織 化学的研究一. 日口外誌 $34: 814 \sim 825,1988$.

22）二階宏昌, 小川郁子, 高田 隆, 他 : 唾液腺腫瘍の免疫組 織化学 一腫瘍性筋上皮の染色所見を中心に一. 病理と臨 床 $7: 574 \sim 581,1989$.

$\left(\begin{array}{l}\text { 原稿受付 : 平成 } 8 \text { 年 } 8 \text { 月 } 21 \text { 日 } \\ \text { 原稿採択 : 平成 } 8 \text { 年 } 9 \text { 月 } 25 \text { 日 } \\ \text { 別刷請求先 : 奥山晃子 } \\ \text { † } 530 \text { 大阪市北区中之島 } 5-2-2 \\ \text { 住友病院耳鼻咽喉科 }\end{array}\right)$

